\title{
Communication \\ On the Control Strategy to Improve the Salt Rejection of a Thin-Film Composite Reverse Osmosis Membrane
}

\author{
Jaewoo Lee ${ }^{1,2, *(D)}$ and Yu Jie $\operatorname{Lim}^{3,4,5}$ (D) \\ 1 Department of Polymer-Nano Science and Technology, Jeonbuk National University, 567 Baekje-daero, \\ Deokjin-gu, Jeonju-si 54896, Korea \\ 2 Department of Bionanotechnology and Bioconvergence Engineering, Jeonbuk National University, \\ 567 Baekje-daero, Deokjin-gu, Jeonju-si 54896, Korea \\ 3 Singapore Membrane Technology Center, Nanyang Environment and Water Research Institute, \\ Nanyang Technological University, Singapore 637141, Singapore; yujie001@e.ntu.edu.sg \\ 4 School of Civil and Environmental Engineering, Nanyang Technological University, \\ Singapore 639798, Singapore \\ 5 Interdisciplinary Graduate Programme, Graduate College, Nanyang Technological University, \\ Singapore 637553, Singapore \\ * Correspondence: jaewoolee@jbnu.ac.kr
}

check for updates

Citation: Lee, J.; Lim, Y.J. On the Control Strategy to Improve the Salt Rejection of a Thin-Film Composite Reverse Osmosis Membrane. Appl. Sci. 2021, 11, 7619. https://doi.org/ 10.3390/app11167619

Academic Editor: José Carlos Magalhães Pires

Received: 20 July 2021

Accepted: 16 August 2021

Published: 19 August 2021

Publisher's Note: MDPI stays neutral with regard to jurisdictional claims in published maps and institutional affiliations.

Copyright: (c) 2021 by the authors. Licensee MDPI, Basel, Switzerland. This article is an open access article distributed under the terms and conditions of the Creative Commons Attribution (CC BY) license (https:// creativecommons.org/licenses/by/ $4.0 /)$.
Featured Application: This article presents a discussion on the gains from enhancing salt rejection from a broad perspective, which includes the specific energy consumption and some insights into a technical direction to improve salt rejection of TFC-RO membranes.

\begin{abstract}
Since the specific energy consumption (SEC) required for reverse osmosis (RO) desalination has been steeply reduced over the past few decades, there is an increasing demand for high-selectivity membranes. However, it is still hard to find research papers empirically dealing with increasing the salt rejection of RO membranes and addressing the SEC change possibly occurring while increasing salt rejection. Herein, we examined the feasibility of the process and material approaches to increase the salt rejection of RO membranes from the perspective of the SEC and weighed up a better approach to increase salt rejection between the two approaches. A process approach was confirmed to have some inherent limitations in terms of the trade-off between water permeability and salt rejection. Furthermore, a process approach is inappropriate to alter the intrinsic salt permeability of RO membranes, such that it should be far from a fundamental improvement in the selectivity of RO membranes. Thus, we could conclude that a material approach is necessary to make a fundamental improvement in the selectivity of RO membranes. This paper also provides discussion on the specific demands for RO membranes featuring superior mechanical properties and excellent water/salt permselectivity to minimize membrane compaction while maximizing the selectivity.
\end{abstract}

Keywords: desalination; reverse osmosis; thin-film composite membrane; salt rejection; selectivity; specific energy consumption

\section{Introduction}

The world has sought a sustainable and environmentally friendly society to overcome the crisis caused by climate change threatening food and water security as well as biodiversity [1-4]. For instance, many countries have been struggling to reduce carbon emissions to about $50 \%$ of 1990 levels by 2030 and reach carbon neutrality by 2050, since the European Green Deal was announced $[5,6]$. To achieve carbon neutrality, it is necessary for humankind to reduce the amount of carbon burned for energy generation in all areas. It is also the case for the industries related to water supply and water infrastructure. Many people have also made continuous efforts to reduce the carbon footprint in membranebased water and wastewater treatment in various ways. For example, researchers have 
tried to improve the energy efficiency required for wastewater treatment using membrane bioreactors via the development of antifouling membranes or cleaning methods [7-9] while producing green energy such as biomethane generated from an anaerobic digestion process [10-12].

An attempt to enhance the energy efficiency in membrane desalination also has a long history. For example, the specific energy consumption (SEC) of a reverse osmosis (RO) process has continuously decreased (from $12 \mathrm{kWh} \mathrm{m}^{-3}$ in the $1970 \mathrm{~s}$ to about $2 \mathrm{kWh} \mathrm{m}^{-3}$ in 2006) over the three decades thanks to the advances in membrane materials as well as module and process designs [13-17]. Consequently, new light was shed on the thought of having to improve the selectivity rather than permeability [18], leading to calls for greater focus on enhancing salt rejection of the membrane to guarantee higher retention of inadequate solutes (e.g., boron $[19,20])$, thereby improving treated water quality while reducing the costs imposed by pre- and post-treatment processes [21,22]. As if to reflect the new trend, research work to meet the demand for improved salt rejection has recently been published [2] in contrast with the existing mainstream to overcome the permeability-selectivity trade-off by enhancing water permeability while maintaining salt rejection [23-25]. However, it is still hard to find research papers empirically dealing with increasing the salt rejection of $\mathrm{RO}$ membranes. In particular, it is rare to find research papers in the literature addressing the SEC change caused by the trade-off between water permeability and salt rejection possibly occurring while increasing the selectivity of $\mathrm{RO}$ membranes.

If improving salt rejection causes the SEC to jump, we will no longer be able to claim that it would take precedence over enhancing water permeability. Note that improving water permeability also brings merits such as a small footprint, saving the membrane area, and cutting down on the cost of chemical cleaning agents and membrane replacement [26]. Accordingly, one should remember that the gains from increasing salt rejection could surpass the benefits resulting from higher water permeability on the condition that it would not be too costly to ameliorate salt rejection (i.e., without a jump in the SEC). With that in mind, this paper examined whether the SEC of an RO process can be significantly influenced by an increase in salt rejection at the expense of a decrease in water permeability. Furthermore, a qualitative assessment of the SEC was carried out to weigh up a better approach to increase salt rejection between material and process perspectives.

\section{Materials and Methods}

Polyamide thin-film composite membranes were prepared with lab-made support membranes via interfacial polymerization as described previously [26,27]. In detail, a $10 \mathrm{wt} \%$ polysulfone (PSf) polymer solution was prepared with the solvent mixture consisting of N-methyl-2-pyrrolidinone (NMP) and N, N-dimethylformamide (DMF) at a ratio of 1:7 to fabricate highly porous microstructured support $(\mathrm{HP} \mu \mathrm{S})$ membranes via non-solvent-induced phase separation (NIPS). The HP $\mu S$ membrane was adopted as a support membrane due to its desired traits such as large surface pores and surface porosity leading to a short effective diffusion path length over an active layer [26], negligible sublayer resistance, which does not affect the overall water flux [28], and excellent mechanical properties enough to withstand high pressure even for seawater reverse osmosis (SWRO) desalination [29]. HP $\mathrm{SS}$ membranes possess extremely high porosity and comparable mechanical strength at the same time, such that they are suitable to prepare highly permeable TFC-RO membranes without compromising salt rejection. This point allowed us to determine how the SEC varies at high water permeability ranges while increasing salt rejection by adjusting an operating parameter.

A polyamide selective layer was prepared via interfacial polymerization on the top side of the $\mathrm{HP} \mu \mathrm{S}$ support membrane using $2 \mathrm{wt} \%$ m-phenylenediamine (MPD) aqueous solutions without and with $1 \mathrm{wt} \%$ dimethyl sulfoxide (DMSO) and a trimesoyl chloride (TMC) solution ( $0.1 w / v \%$; solvent: $n$-hexane). The TFC membranes prepared without and with $1 \mathrm{wt} \%$ DMSO were marked as TFC-D0 and TFC-D1, respectively. $1 \mathrm{wt} \%$ DMSO can form a highly permeable polyamide active layer $\left(5.14 \mathrm{~L} \mathrm{~m}^{-2} \mathrm{~h}^{-1}\right.$ bar $^{-1}$; in brackish water 
reverse osmosis (BWRO)) with comparable salt rejection (98.3\%; in BWRO) by inducing a smooth, thin, and slightly loose polyamide layer via the dipole-dipole interaction between DMSO and carbonyl oxygens of TMC [27].

Cross-sectional SEM images were taken to observe the morphologies of support membranes and measure a mean active layer thickness using FESEM (Field-emission scanning electron microscopy, JSM-7600F, JEOL, Japan). The average values of the active layer thickness were estimated using the thicknesses measured at five arbitrary positions, as described previously [30-33]. The active layer roughness was evaluated with an atomic force microscope (AFM; NX10, Park Systems, Suwon, Korea). A Fourier transform infrared (FTIR) spectrometer (IR Prestige-21, Shimadzu, Japan) equipped with attenuated total reflection (ATR) was used to observe the change in the peak intensity at $950 \mathrm{~cm}^{-1}$, as described previously $[27,34]$, in order to determine whether $1 \mathrm{wt} \%$ DMSO slightly decreased the crosslinking degree. The peak with a larger intensity at $950 \mathrm{~cm}^{-1}$ indicates more unreacted acyl chloride groups on a polyamide active layer, implying a lower crosslinking degree.

The membrane filtration test was carried out without a spacer to obtain the water flux $\left(\mathrm{L} \mathrm{m}^{-2} \mathrm{~h}^{-1} \mathrm{bar}^{-1} ; \mathrm{LMH}\right)$ and salt rejection $\left(R=C_{p} / C_{f} ; \%\right)$ under increasing applied pressure from 25 to 55 bar in a bid to explore the possibility of increasing salt rejection by adjusting operating pressures. In addition, this allows us to compare the benefits between a process approach and a material approach from the perspective of the SEC. $C_{f}$ and $C_{p}$ refer to the salt concentrations of the feed and permeate solutions, respectively. When $C_{f}$ was used to calculate the $R$, the concentration polarization phenomenon, which is variable depending on the use of a spacer and spacers' geometry [35], was excluded from consideration. A TFC membrane larger than $42 \mathrm{~cm}^{2}$ was used to assess the water flux and salt rejection using a $2000 \mathrm{ppm} \mathrm{NaCl}$ solution at $25^{\circ} \mathrm{C}$.

A temperature influence on the SEC was excluded from consideration although the temperature could affect the SEC by decreasing the fluid viscosity or increasing the osmotic pressure of the feed solution [36], since the filtration test was performed at a constant temperature. Apart from concentration polarization and temperature influence, the other operating parameters affecting the $\mathrm{RO}$ water production cost (e.g., pretreatment and management costs, control schemes, and process configuration [18]) were also excluded from consideration under the assumption that there would be no difference between the tests of the control and experimental samples with regard to those operating parameters.

Membrane compaction was conducted for $30 \mathrm{~min}$ at 25 bar prior to collecting the permeate solutions used to evaluate the water flux and salt rejection. After membrane compaction, the permeate solutions were collected for $10 \mathrm{~min}$ at different operating pressures. The water permeability coefficient $(A)$ and salt permeability coefficient $(B)$ were obtained from the following relationship:

$$
\begin{gathered}
A=\frac{J_{v}}{\mathbf{T M P}-\Delta \pi} \\
B=\frac{(1-R) \cdot A \cdot(\boldsymbol{T M P}-\Delta \pi)}{R}
\end{gathered}
$$

where $J_{v}$ is the volumetric water flux, TMP is the pressure difference across the membrane, and $\Delta \pi$ is the osmotic pressure difference across the membrane.

\section{Results and Discussion}

The HP $\mu$ S membrane and TFC membrane were characterized in terms of support morphologies and active layer characteristics, respectively. When it comes to the active layer characteristics, the active layer thickness, roughness, and crosslinking degree were investigated to double-check whether $1 \mathrm{wt} \%$ DMSO worked properly to improve the water permeability without compromising salt rejection, as described previously [27]. According to our observations (Figure $1 \mathrm{a}-\mathrm{c}$ ), $1 \mathrm{wt} \%$ DMSO led to a thinner and smoother active layer with slightly more unreacted acyl chlorides (evidenced by the slightly larger intensity at $950 \mathrm{~cm}^{-1}$ ). The thinner active layer with a slightly lower crosslinking degree at a moderate 
level was expected to increase water permeability without compromising salt rejection. The as-prepared $\mathrm{HP} \mu \mathrm{S}$ membrane was confirmed to have narrow and regular columnar macrovoids (Figure 1d), as reported previously [26]. The phenomenon is attributable to the fact that the solvent mixture (NMP: DMF $=1: 7$ ) induces rapid desolvation by enhancing the thermodynamic instability of a PSf polymer solution. The HP $\mu$ S membrane was expected to endure high pressure ranging from 25 to 55 bar owing to the unique structural characteristics.

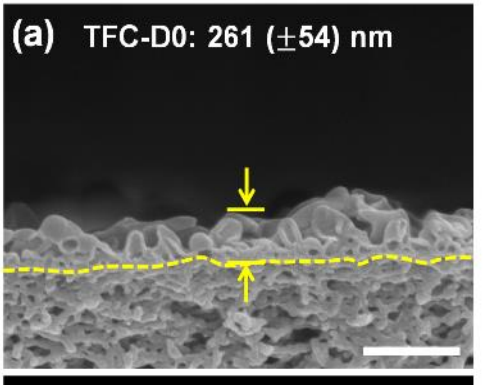

TFC-D1: 212 ( \pm 28$) \mathrm{nm}$

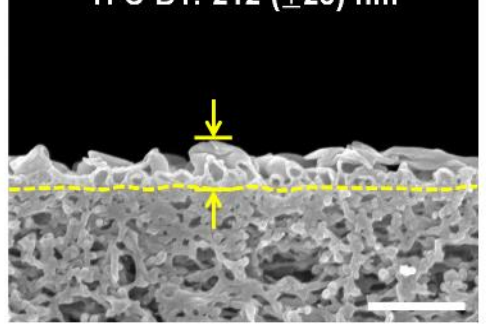

(b)

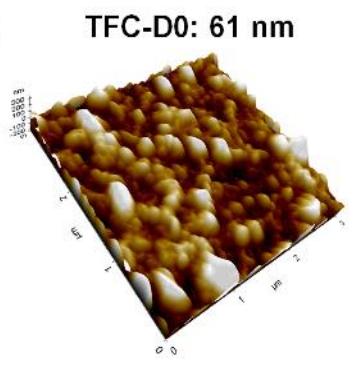

TFC-D1: $53 \mathrm{~nm}$

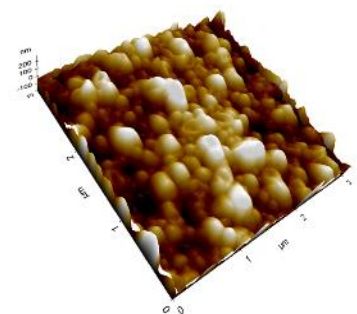

(c)
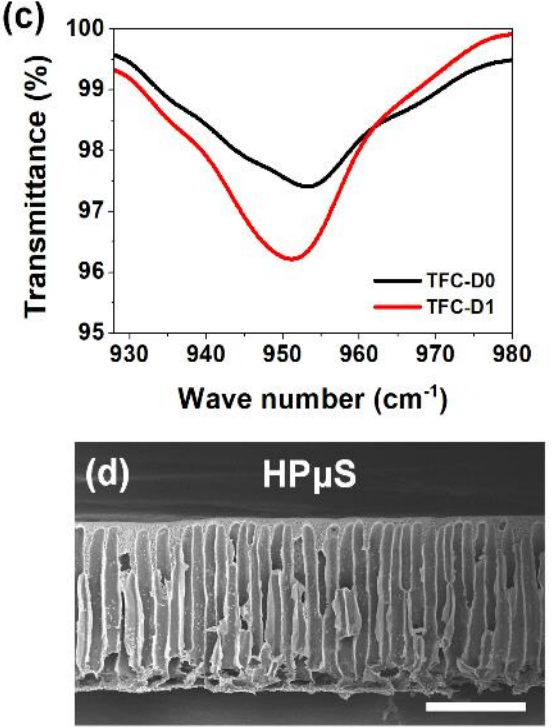

Figure 1. (a) Cross-sectional SEM images (Scale bar: $500 \mathrm{~nm}$ ) and (b) AFM images of TFC-D0 (top) and TFC-D1 (bottom) membranes with the average thickness and roughness values of the active layers, respectively. (c) FTIR spectra of TFC-D0 and TFC-D1 membranes observed at $950 \mathrm{~cm}^{-1}$. (d) Cross-sectional SEM image of the HP $\mu \mathrm{S}$ membrane (Scale bar: $\left.50 \mu \mathrm{m}\right)$.

Figure 2a,b show the as-prepared TFC-D1 membrane's water flux, salt rejection, $A$, and $B$ values measured at different operating pressures, respectively. The water flux and salt rejection of the TFC-D1 membrane were $5.54 \mathrm{LMH} /$ bar and $98.9 \%$ at 25 bar, which looks reasonable as compared to the previous result [27]. However, as the operating pressure increased from 25 to 55 bar, the $A$ value was reduced from 5.54 to $3.31 \mathrm{LMH} /$ bar while salt rejection increased from $98.9 \%$ to $99.3 \%$. This phenomenon is likely to arise from membrane compaction as the pressure difference across the membrane increases. It seems understandable that membrane compaction was accompanied by a decreased $A$ value and higher salt rejection, but two points caught our eye. First, a process approach to increase salt rejection (for example, by applying a higher pressure) will not allow us to overcome the trade-off between water permeability and salt rejection since the trade-off is intrinsically linked with the properties of the polyamide layer, according to empirical evidence [13,37]. Consequently, the process approach of increasing operating pressure will entail a higher energy consumption (i.e., SEC will increase). Second, unlike variable $A$ value and salt rejection which change with applied pressure, $B$ value was nearly constant throughout the entire operating pressure range. This phenomenon is ascribed to the fact that ion transport is mainly governed by the concentration gradient, which would be almost constant at the same recovery rate regardless of applied pressure. This result suggests that a process approach could not make a fundamental change in the improvement of the selectivity of $\mathrm{RO}$ membranes, although it could result in a bit higher salt rejection apparently at the expense of a lower $A$ value. 
(a)

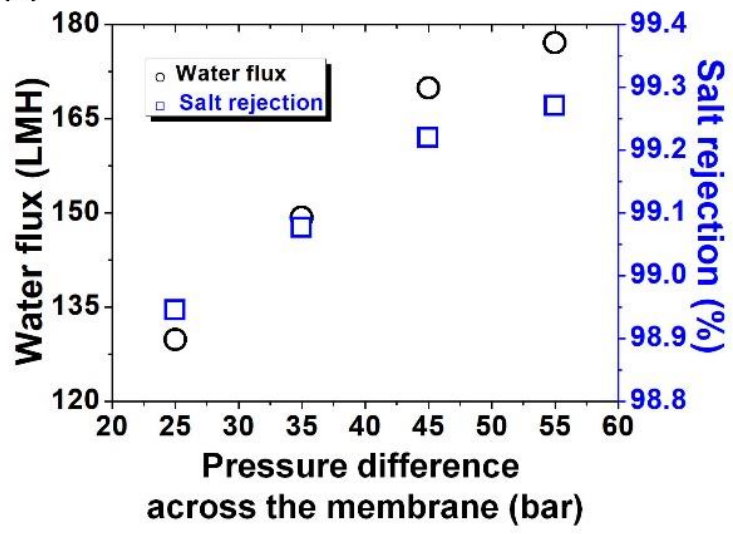

(b)

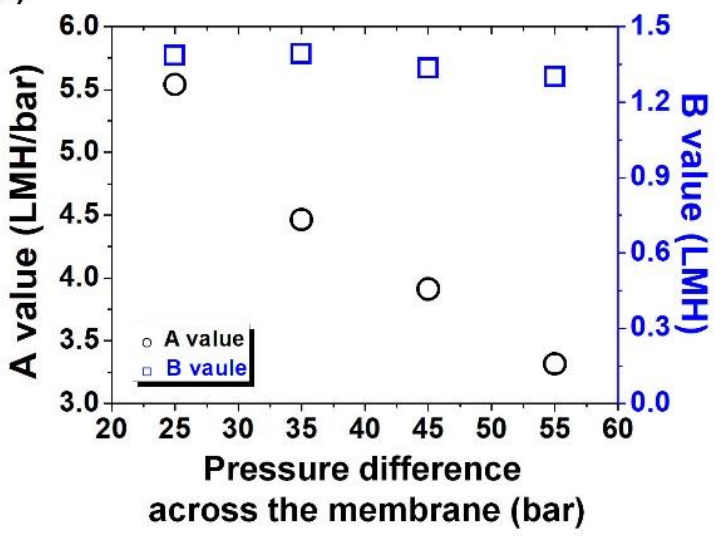

Figure 2. (a) Water flux and salt rejection and (b) water permeability and salt permeability coefficients of the TFC-D1 membrane at different applied pressures.

Our observation implies that a material approach is required to achieve a fundamental improvement in the selectivity of $\mathrm{RO}$ membranes. For instance, the high-selectivity $\mathrm{RO}$ membrane was recently developed using porous nanomaterials called cucurbit[6]uril (CB[6]; it features $0.39 \mathrm{~nm}$ pores with a partially negative charge) and demonstrated that it could significantly reduce salt permeability to half of its original value (1.29 to $0.66 \mathrm{LMH})$ without significant flux decline (4.30 to $4.01 \mathrm{LMH} /$ bar) owing to selective water transport over monovalent ions [2]. This result indicates that a CB[6] thin-film nanocomposite (TFN) membrane could achieve high salt rejection almost without paying the price for the increased SEC, unlike a process approach. To qualitatively weigh up the SEC change stemming from the process and material approaches to improve salt rejection, we roughly estimated the ideal SEC $\left(\mathrm{SEC}_{\mathrm{i}}\right)$ obtainable under ideal operating conditions (i.e., no leakage of energy recovery devices (ERD), perfect pressure transfer efficiency of ERD, and perfect overall pump efficiency) without consideration of the salt concentration based on the following relationship [38]:

$$
\mathrm{SEC}_{\mathrm{i}}=\left(\frac{1-R_{w}}{R_{w}}\right) \Delta P+\left(P_{f}-P_{o}\right)
$$

where $R_{w}$ is the desalinated water recovery, $\Delta P$ is the pressure difference across the membrane module, $P_{f}$ is the feed pressure, and $P_{o}$ is the permeate pressure. The unit of $\mathrm{SEC}_{\mathrm{i}}$ can be converted from $\mathrm{Pa}$ to $\mathrm{kWh} / \mathrm{m}^{3}$ with a conversion factor $\left(3.6 \times 10^{6} \mathrm{~Pa} \approx 1.0 \mathrm{kWh} / \mathrm{m}^{3}\right)$. If $R_{w}$ is constant while $\Delta P$ and $P_{o}$ are negligible for simplifications, the $S E C_{\mathrm{i}}$ has a nearly linear correlation with $P_{f}$. In this regard, a process approach such as increasing applied pressure should accept an additional concomitant $S E C_{i}$. In contrast, a material approach does not increase the $\mathrm{SEC}_{\mathrm{i}}$, since it does not require a change of applied pressure.

Furthermore, the correlation between water permeability and SEC also supports that a material approach is more beneficial than a process approach. Specifically, the SEC soars as water permeability drops (Figure 3) according to the correlation between water permeability and SEC obtainable from the data for BWRO in the previous study [39]. Given that a process approach entailed a significant loss of water permeability (5.54 to $3.31 \mathrm{LMH} /$ bar; about a $40 \%$ reduction), it is not a surprise that a process approach may be accompanied by a substantial increase in the SEC. On the other hand, the SEC change by a material approach is likely to be negligible, as evidenced by the CB[6] TFN membrane exhibiting only a marginal reduction in water permeability (4.30 to $4.01 \mathrm{LMH} /$ bar; about a $7 \%$ reduction). Although a quantitative assessment could not be made with regard to the SEC due to the lack of information required to model at different pressures with variable salt rejection, those qualitative comparisons showed which approach we need to pursue to improve the selectivity of $\mathrm{RO}$ membranes without a substantial increase in the SEC (i.e., a 
material approach is necessary to make a fundamental improvement in the selectivity of RO membranes).

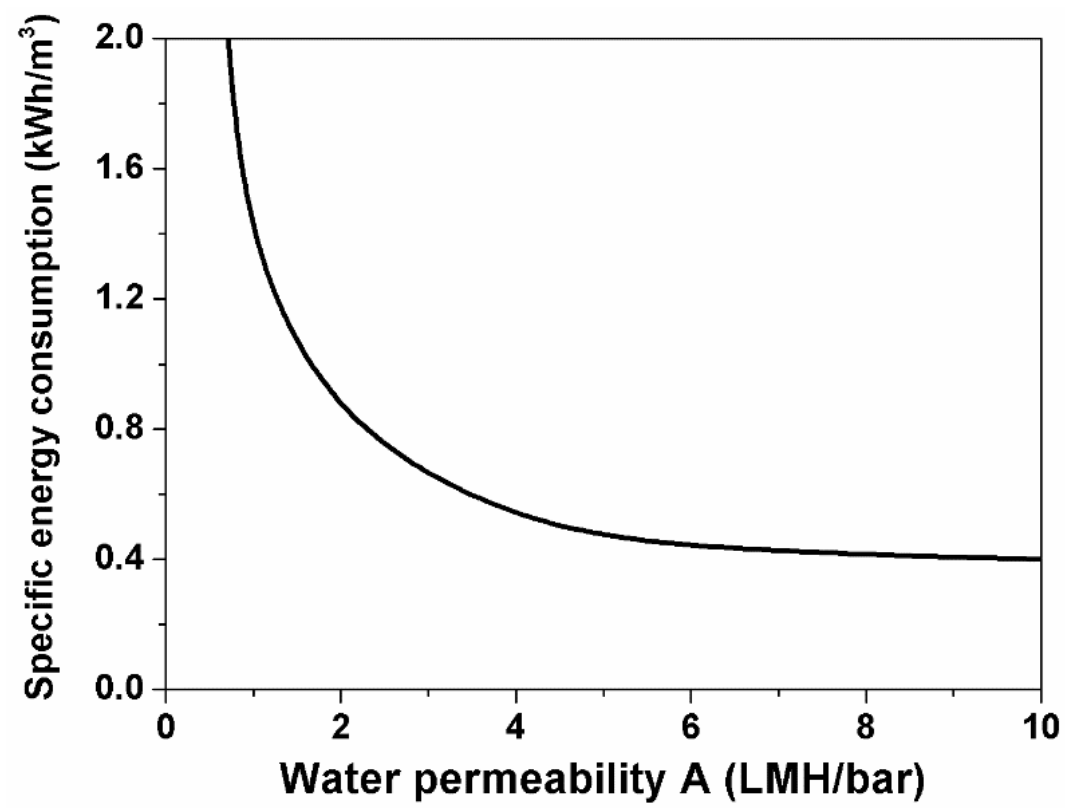

Figure 3. The specific energy consumption (SEC) as a function of membrane permeability. The SEC was plotted based on the data for BWRO summarized from Cohen-Tanugi et al. [39]. BWRO is modeled with a $2000 \mathrm{ppm} \mathrm{NaCl}$ feed solution at $65 \%$ recovery.

Lastly, it is worth exploring which materials have the potential to increase the selectivity of the commonly used $\mathrm{RO}$ membranes (i.e., polyamide $\mathrm{RO}$ membranes) in the field and what conditions need to be satisfied to make high-performance RO membranes with high selectivity. As for the specific way to a valid material approach, fabricating thin-film nanocomposite (TFN) RO membranes using porous nanomaterials could be the most appropriate as of now in that the approach can make the existing manufacturing lines to produce conventional $\mathrm{RO}$ membranes readily available, facilitating the commercialization of newly developed membranes. When it comes to the potential nanomaterials, it would be desirable to possess pores with low tortuosity and adequate size falling between hydrated ions $\left(\mathrm{Na}^{+}: 7.2 \AA ; \mathrm{Cl}^{-}: 6.6 \AA\right.$ ) and water molecules (about $2.75 \AA$ ) to effectively inhibit the salt passage while allowing water passage, thereby increasing the selectivity without significant loss of water permeability. If one tries preparing highly selective RO membranes using porous nanomaterials with larger pores than hydrated ions, the interior surface functionalization of the nanomaterials will need to be carried out as demonstrated in the previous simulation [40]. A few porous nanomaterials are listed in Table 1 as potential candidates that could be used to prepare highly selective $\mathrm{RO}$ membranes without compromising water permeability.

However, this does not necessarily mean that porous nanomaterials with the pore size corresponding to the above ranges always meet the requirement to make highly selective $\mathrm{RO}$ membranes due to some performance influence factors. First, porous nanomaterials need to be individually incorporated in an active layer during interfacial polymerization to ensure their intrinsic properties, in terms of selective water transport, are clearly exhibited in an active layer during filtration. If porous nanomaterials were incorporated in an active layer in the form of aggregates (e.g., zeolite) or used after being embedded in much larger materials (e.g., aquaporin Z), it could be hard to demonstrate their intrinsic material effects regarding selective water transport due to the interstitial space between individual nanoparticles or the gap between the vesicle and the polymer matrix of an active layer. It is also essential that interfacial polymerization should not be significantly affected by nano-additives because there is concern that polyamide chains' changes (e.g., variable 
crosslinking degree), possibly caused by the additives, may cancel out the addition effect of the porous nanomaterials. Lastly, the pore size of an active layer needs to be controlled as low as those of the used porous nanomaterials. If the polymer matrix in an active layer has even larger pores than the nano-additives, diffusion species will pass mainly through the pores of the loose polymer matrix instead of the pores of the nano-additives. This too will preclude us from observing the intrinsic characteristics regarding selective water transport of porous nanomaterials.

Table 1. Potential porous nanomaterials to prepare highly selective RO membranes.

\begin{tabular}{|c|c|c|c|c|c|c|}
\hline Material & $\begin{array}{l}\text { Pore } \\
\text { Size }\end{array}$ & Other Features & Incorporation Type & $\begin{array}{c}\text { Control } \\
\text { Membrane's } \\
\text { Salt } \\
\text { Rejection }\end{array}$ & $\begin{array}{l}\text { Effect of } \\
\text { Porous Nano- } \\
\text { materials }\end{array}$ & Ref. \\
\hline $\mathrm{CB}[6]$ & $3.9 \AA$ & $\begin{array}{l}\text { - Negligible entry resistance for } \\
\text { water molecules } \\
\text { - } \quad \text { Hydrophilic and partially negative } \\
\text { charged carbonyl-fringed portals } \\
\text { - } \quad \text { Rigid }\end{array}$ & $\begin{array}{l}\text { Individually } \\
\text { incorporated in } \\
\text { an active layer }\end{array}$ & $97.8 \%$ & $\begin{array}{l}\text { Improved } \\
\text { selectivity }\end{array}$ & [2] \\
\hline $\begin{array}{l}\text { Peptide- } \\
\text { appended } \\
\text { pil- } \\
\text { lar[5]arene }\end{array}$ & $\sim 5 \AA$ & $\begin{array}{l}\text { - } \quad \text { Synthetic nanochannel } \\
\text { - Macrocyclic structure resembling a } \\
\text { carbon nanotube } \\
\text { Peptide-appended arms governing } \\
\text { the channel length }\end{array}$ & $\begin{array}{l}\text { Incorporated in } \\
\text { an active layer } \\
\text { after embedded } \\
\text { in liposomes } \\
(100-150 \mathrm{~nm})\end{array}$ & $98.2 \%$ & $\begin{array}{c}\text { Improved } \\
\text { permeability }\end{array}$ & {$[34]$} \\
\hline $\begin{array}{c}\text { Aquaporin } \\
\mathrm{Z}\end{array}$ & $\begin{array}{c}2.8 \AA \\
{[41]}\end{array}$ & $\begin{array}{l}\text { - Wild type } \\
\text { Water permeability of } 0.06 \mathrm{~cm} \mathrm{~s}^{-1} \\
\text { in case of the proteoliposomes } \\
\text { with AqpZ wild type prepared } \\
\text { based on the protein to lipid molar } \\
\text { ratio of 1:200 }\end{array}$ & $\begin{array}{l}\text { Incorporated in } \\
\text { an active layer } \\
\text { after embedded } \\
\text { in liposomes } \\
(100-150 \mathrm{~nm})\end{array}$ & $96 \%$ & $\begin{array}{c}\text { Improved } \\
\text { permeability }\end{array}$ & [42] \\
\hline Zeolite & $4 \AA$ & $\begin{array}{l}\text { - } \quad \text { Inorganic porous nanomaterials } \\
\text { - } \quad \text { NaA-type } \\
\text { Small, super-hydrophilic, and } \\
\text { negatively charged pores }\end{array}$ & $\begin{array}{l}\text { Incorporated in } \\
\text { an active layer } \\
\text { in the form of } \\
\text { aggregates } \\
(50-150 \mathrm{~nm})\end{array}$ & $93.4 \%$ & $\begin{array}{c}\text { Improved } \\
\text { permeability }\end{array}$ & [43] \\
\hline
\end{tabular}

\section{Conclusions}

In this study, we explored which technical path would be more desirable to make a fundamental improvement in the selectivity of $\mathrm{RO}$ membranes without compromising the competitiveness from the perspective of energy consumption. We prepared a highly permeable TFC membrane with an $\mathrm{HP} \mu \mathrm{S}$ membrane via interfacial polymerization using $1 \mathrm{wt} \%$ DMSO. Subsequently, we obtained its water permeability and salt rejection by adjusting an applied pressure from 25 to 55 bar as a process approach to estimate the SEC change occurring while varying a process parameter and qualitatively compare the degree of the SEC increase with that of the previous study via a material approach. The qualitative comparison revealed there could be quite a significant difference in the degree of the SEC increase between process and material approaches based on the difference in flux decline occurring during each approach. This difference is assumed to arise from a couple of inherent limitations of a process approach. First, a process approach could not overcome the trade-off between water permeability and salt rejection, inevitably making the SEC skyrocket while increasing salt rejection. Second, a process approach cannot alter the intrinsic selectivity of $\mathrm{RO}$ membranes, such that it is impossible to make a fundamental change in the permselectivity regardless of bringing benefits in energy consumption. In this regard, a material approach must be provided to enhance the salt rejection of $\mathrm{RO}$ membranes. There are two demands from the perspective of a material approach. The first demand is for superior mechanical properties endurable to membrane compaction, which 
causes severe flux decline and thereby increases energy burdens during a high-pressure desalination process. The second demand is for excellent water/salt permselectivity capable of significantly improving salt rejection of $\mathrm{RO}$ membranes with no substantial flux decline. Apart from the two demands on highly selective RO membranes, it is also necessary to have regard to the fouling effect, deteriorating the RO membrane performance by increasing solute permeability coefficient and/or decreasing the water permeability coefficient $[18,20]$.

Author Contributions: Conceptualization, J.L.; methodology, J.L.; validation, J.L. and Y.J.L.; formal analysis, J.L. and Y.J.L.; investigation, J.L. and Y.J.L.; resources, J.L.; data curation, J.L.; writingoriginal draft preparation, J.L.; writing-review and editing, J.L. and Y.J.L.; visualization, J.L.; supervision, J.L.; project administration, J.L.; funding acquisition, J.L. All authors have read and agreed to the published version of the manuscript.

Funding: Jaeweoo Lee would like to thank Jeonbuk National University for the financial support.

Institutional Review Board Statement: Not applicable.

Informed Consent Statement: Not applicable.

Conflicts of Interest: The authors declare no conflict of interest.

\section{References}

1. Lee, J.; Jang, J.H.; Chae, H.-R.; Lee, S.H.; Lee, C.-H.; Park, P.-K.; Won, Y.-J.; Kim, I.-C. A facile route to enhance the water flux of a thin-film composite reverse osmosis membrane: Incorporating thickness-controlled graphene oxide into a highly porous support layer. J. Mater. Chem. A 2015, 3, 22053-22060. [CrossRef]

2. Lee, J.; Zhou, F.; Baek, K.; Kim, W.; Su, H.; Kim, K.; Wang, R.; Bae, T.-H. Use of rigid cucurbit[6] uril mediating selective water transport as a potential remedy to improve the permselectivity and durability of reverse osmosis membranes. J. Membr. Sci. 2021, 623, 119017. [CrossRef]

3. Sethunga, G.; Lee, J.; Wang, R.; Bae, T.-H. Influences of operating parameters and membrane characteristics on the net energy production in dense, porous, and composite hollow fiber membrane contactors for dissolved biomethane recovery. J. Membr. Sci. 2020, 610, 118301. [CrossRef]

4. Lim, Y.J.; Lee, S.M.; Wang, R.; Lee, J. Emerging Materials to Prepare Mixed Matrix Membranes for Pollutant Removal in Water. Membranes 2021, 11, 508. [CrossRef] [PubMed]

5. Sikora, A. European Green Deal-legal and financial challenges of the climate change. ERA Forum 2021, 21, 681-697. [CrossRef]

6. Alam, S.; Kumar, A.; Dawes, L. Roughness optimization of road networks: An option for carbon emission reduction by 2030. J. Transp. Eng. Part. B Pavements 2020, 146, 04020062. [CrossRef]

7. Lee, J.; Chae, H.-R.; Won, Y.J.; Lee, K.; Lee, C.-H.; Lee, H.H.; Kim, I.-C.; Lee, J.-M. Graphene Oxide Nanoplatelets Composite Membrane with Hydrophilic and Antifouling Properties for Wastewater Treatment. J. Membr. Sci. 2013, 448, 223-230. [CrossRef]

8. Lee, J.; Won, Y.-J.; Choi, D.-C.; Lee, S.; Park, P.-K.; Choo, K.-H.; Oh, H.-S.; Lee, C.-H. Micro-patterned membranes with enzymatic quorum quenching activity to control biofouling in an MBR for wastewater treatment. J. Membr. Sci. 2019, 592, 117365. [CrossRef]

9. Yao, W.; Wang, Z.; Wang, X. Detachment mechanism and energy consumption model for the ex-situ rinsing process in membrane bioreactors. J. Membr. Sci. 2020, 615, 118462. [CrossRef]

10. Rongwong, W.; Lee, J.; Goh, K.; Karahan, H.E.; Bae, T.-H. Membrane-based technologies for post-treatment of anaerobic effluents. NPJ Clean Water 2018, 1, 1-11. [CrossRef]

11. Sethunga, G.; Lee, J.; Wang, R.; Bae, T.-H. Influence of membrane characteristics and operating parameters on transport properties of dissolved methane in a hollow fiber membrane contactor for biogas recovery from anaerobic effluents. J. Membr. Sci. 2019, 589, 117263. [CrossRef]

12. Sethunga, G.; Karahan, H.E.; Wang, R.; Bae, T.-H. Wetting-and fouling-resistant hollow fiber membranes for dissolved methane recovery from anaerobic wastewater treatment effluents. J. Membr. Sci. 2021, 617, 118621. [CrossRef]

13. Lim, Y.J; Goh, K.; Kurihara, M.; Wang, R. Seawater desalination by reverse osmosis: Current development and future challenges in membrane fabrication-A review. J. Membr. Sci. 2021, 629, 119292. [CrossRef]

14. Lee, K.P.; Arnot, T.C.; Mattia, D. A review of reverse osmosis membrane materials for desalination-development to date and future potential. J. Membr. Sci. 2011, 370, 1-22. [CrossRef]

15. Chong, T.H.; Loo, S.-L.; Krantz, W.B. Energy-efficient reverse osmosis desalination process. J. Membr. Sci. 2015, 473, 177-188. [CrossRef]

16. Chong, T.H.; Loo, S.-L.; Fane, A.G.; Krantz, W.B. Energy-efficient reverse osmosis desalination: Effect of retentate recycle and pump and energy recovery device efficiencies. Desalination 2015, 366, 15-31. [CrossRef]

17. Chong, T.H.; Krantz, W.B. Process economics and operating strategy for the energy-efficient reverse osmosis (EERO) process. Desalination 2018, 443, 70-84. [CrossRef] 
18. Zhu, A.; Christofides, P.D.; Cohen, Y. On RO membrane and energy costs and associated incentives for future enhancements of membrane permeability. J. Membr. Sci. 2009, 344, 1-5. [CrossRef]

19. Ruiz-García, A.; Nuez, I. Performance evaluation and boron rejection in a SWRO system under variable operating conditions. Comput. Chem. Eng. 2021, 153, 107441. [CrossRef]

20. Ruiz-García, A.; León, F.; Ramos-Martín, A. Different boron rejection behavior in two RO membranes installed in the same full-scale SWRO desalination plant. Desalination 2019, 449, 131-138. [CrossRef]

21. Werber, J.R.; Deshmukh, A.; Elimelech, M. The critical need for increased selectivity, not increased water permeability, for desalination membranes. Environ. Sci. Technol. Lett. 2016, 3, 112-120. [CrossRef]

22. Okamoto, Y.; Lienhard, J.H. How RO membrane permeability and other performance factors affect process cost and energy use: A review. Desalination 2019, 470, 114064. [CrossRef]

23. Shin, M.G.; Seo, J.Y.; Park, H.; Park, Y.-I.; Lee, J.-H. Overcoming the permeability-selectivity trade-off of desalination membranes via controlled solvent activation. J. Membr. Sci. 2021, 620, 118870. [CrossRef]

24. Gai, W.; Zhang, Y.; Zhao, Q.; Chung, T.-S. Highly permeable thin film composite hollow fiber membranes for brackish water desalination by incorporating amino functionalized carbon quantum dots and hypochlorite treatment. J. Membr. Sci. 2021, 620, 118952. [CrossRef]

25. Li, W.-X.; Yang, Z.; Liu, W.-L.; Huang, Z.-H.; Zhang, H.; Li, M.-P.; Ma, X.-H.; Tang, C.Y.; Xu, Z.-L. Polyamide reverse osmosis membranes containing 1D nanochannels for enhanced water purification. J. Membr. Sci. 2021, 618, 118681. [CrossRef]

26. Lee, J.; Wang, R.; Bae, T.-H. High-performance reverse osmosis membranes fabricated on highly porous microstructured supports. Desalination 2018, 436, 48-55. [CrossRef]

27. Lee, J.; Wang, R.; Bae, T.-H. A comprehensive understanding of co-solvent effects on interfacial polymerization: Interaction with trimesoyl chloride. J. Membr. Sci. 2019, 583, 70-80. [CrossRef]

28. Lee, J.; Yoon, H.; Yoo, J.H.; Choi, D.-C.; Nahm, C.H.; Lee, S.H.; Chae, H.-R.; Kim, Y.H.; Lee, C.-H.; Park, P.-K. Influence of the sublayer structure of thin-film composite reverse osmosis membranes on the overall water flux. Environ. Sci. Water Res. Technol. 2018, 4, 1912-1922. [CrossRef]

29. Lim, Y.J.; Lee, J.; Bae, T.-H.; Torres, J.; Wang, R. Feasibility and performance of a thin-film composite seawater reverse osmosis membrane fabricated on a highly porous microstructured support. J. Membr. Sci. 2020, 611, 118407. [CrossRef]

30. Liu, Y.; Bai, L.; Zhu, X.; Xu, D.; Li, G.; Liang, H.; Wiesner, M.R. The role of carboxylated cellulose nanocrystals placement in the performance of thin-film composite (TFC) membrane. J. Membr. Sci. 2021, 617, 118581. [CrossRef]

31. Wang, Z.-Y.; Wang, Y.-C.; Wang, W.-J.; Tao, S.-N.; Chen, Y.-F.; Tang, M.; Shao, D.-D.; Xing, W.; Sun, S.-P. Designing scalable dual-layer composite hollow fiber nanofiltration membranes with fully cross-linked ultrathin functional layer. J. Membr. Sci. 2021, 628, 119243. [CrossRef]

32. Wang, Q.; Wei, X.; Wang, G.-R.; Lu, T.-D.; Shi, Q.; Sun, S.-P. Inner-selective coordination nanofiltration hollow fiber membranes from assist-pressure modified substrate. J. Membr. Sci. 2021, 626, 119186. [CrossRef]

33. Liu, Y.; Gao, J.; Ge, Y.; Yu, S.; Liu, M.; Gao, C. A combined interfacial polymerization and in-situ sol-gel strategy to construct composite nanofiltration membrane with improved pore size distribution and anti-protein-fouling property. J. Membr. Sci. 2021, 623, 119097. [CrossRef]

34. Lim, Y.J.; Goh, K.; Lai, G.S.; Ng, C.Y.; Torres, J.; Wang, R. Fast water transport through biomimetic reverse osmosis membranes embedded with peptide-attached (pR)-pillar [5] arenes water channels. J. Membr. Sci. 2021, 628, 119276. [CrossRef]

35. Ruiz-García, A.; de la Nuez Pestana, I. Feed spacer geometries and permeability coefficients. Effect on the performance in BWRO spriral-wound membrane modules. Water 2019, 11, 152. [CrossRef]

36. Koutsou, C.; Kritikos, E.; Karabelas, A.; Kostoglou, M. Analysis of temperature effects on the specific energy consumption in reverse osmosis desalination processes. Desalination 2020, 476, 114213. [CrossRef]

37. Park, H.B.; Kamcev, J.; Robeson, L.M.; Elimelech, M.; Freeman, B.D. Maximizing the right stuff: The trade-off between membrane permeability and selectivity. Science 2017, 356, 6343. [CrossRef]

38. Karabelas, A.; Koutsou, C.; Kostoglou, M.; Sioutopoulos, D. Analysis of specific energy consumption in reverse osmosis desalination processes. Desalination 2018, 431, 15-21. [CrossRef]

39. Cohen-Tanugi, D.; McGovern, R.K.; Dave, S.H.; Lienhard, J.H.; Grossman, J.C. Quantifying the potential of ultra-permeable membranes for water desalination. Energy Environ. Sci. 2014, 7, 1134-1141. [CrossRef]

40. Lyu, Q.; Kang, D.-Y.; Hu, S.; Lin, L.-C. Exploiting interior surface functionalization in reverse osmosis desalination membranes to mitigate permeability-selectivity trade-off: Molecular simulations of nanotube-based membranes. Desalination 2020, $491,114537$. [CrossRef]

41. Savage, D.F.; Egea, P.F.; Robles-Colmenares, Y.; III, J.D.O.C.; Stroud, R.M. Architecture and selectivity in aquaporins: $2.5 \AA$ X-ray structure of aquaporin Z. PLoS Biol. 2003, 1, e72. [CrossRef] [PubMed]

42. Zhao, Y.; Qiu, C.; Li, X.; Vararattanavech, A.; Shen, W.; Torres, J.; Helix-Nielsen, C.; Wang, R.; Hu, X.; Fane, A.G.; et al. Synthesis of robust and high-performance aquaporin-based biomimetic membranes by interfacial polymerization-membrane preparation and RO performance characterization. J. Membr. Sci. 2012, 423, 422-428. [CrossRef]

43. Jeong, B.-H.; Hoek, E.M.; Yan, Y.; Subramani, A.; Huang, X.; Hurwitz, G.; Ghosh, A.K.; Jawor, A. Interfacial polymerization of thin film nanocomposites: A new concept for reverse osmosis membranes. J. Membr. Sci. 2007, 294, 1-7. [CrossRef] 